\title{
A PRACTICE-BASED THEORY OF DIVERSITY: RE-SPECIFYING (IN)EQUALITY IN ORGANIZATIONS
}

\begin{tabular}{|c|l|}
\hline Journal: & Academy of Management Review \\
\hline Manuscript ID & AMR-2017-0062-STFDIV.R4 \\
\hline Manuscript Type: & STF Diversity \\
\hline Topic Areas: $:$ & $\begin{array}{l}\text { Gender and Diversity in Organizations, Diversity and change } \\
\text { Organizational Development and Change, Diversity management } \\
\text { Human Resource Management and Industrial Relations }\end{array}$ \\
\hline Abstract: & $\begin{array}{l}\text { This paper turns to practice theory as a new theoretical lens to better } \\
\text { understand the complexity of diversity in organizations. Questioning the } \\
\text { field's ontological dualism between individualism and societism, we } \\
\text { propose to engage with practice theory's relational ontology and its main } \\
\text { conceptual and methodological ideas. From this, we develop a practice- } \\
\text { based theory of diversity, arguing that practices and their connections, } \\
\text { not individuals or discourses, are the unit of analysis to study and } \\
\text { understand the social life of a diverse organization. We apply this } \\
\text { theoretical lens to (in)equality through two research examples, showing } \\
\text { how the practicing of career mentoring is connected with other } \\
\text { inequality-(re)producing practices, and how the equal social order of a } \\
\text { dance organization is accomplished through the situated practice of } \\
\text { mixing. In the discussion, we highlight the value of a practice theory for } \\
\text { diversity. A practice-based theory of diversity renews the research } \\
\text { agenda of diversity studies, forwarding post-dualistic forms of theorizing, } \\
\text { re-conceptualizing diversity practices along the theoretical logic of } \\
\text { practice, and conceiving diversity-related phenomena as the net-effect of } \\
\text { social order-producing practices. }\end{array}$ \\
\hline
\end{tabular}




\title{
A PRACTICE-BASED THEORY OF DIVERSITY: \\ RE-SPECIFYING (IN)EQUALITY IN ORGANIZATIONS
}

\author{
Maddy Janssens \\ KU Leuven \\ maddy.janssens@kuleuven.be \\ $\&$
}

Chris Steyaert

St. Gallen University

chris.steyaert@unisg.ch

\begin{abstract}
We are very grateful to the three anonymous reviewers for their engaging, critical yet constructive feedback. We further thank the STF editorial team and are especially deeply indebted to Professor Stella Nkomo for her supportive and precise guidance during each stage of the review process.
\end{abstract}




\begin{abstract}
This paper turns to practice theory as a new theoretical lens to better understand the complexity of diversity in organizations. Questioning the field's ontological dualism between individualism and societism, we propose to engage with practice theory's relational ontology and its main conceptual and methodological ideas. From this, we develop a practice-based theory of diversity, arguing that practices and their connections, not individuals or discourses, are the unit of analysis to study and understand the social life of a diverse organization. We apply this theoretical lens to (in)equality through two research examples, showing how the practicing of career mentoring is connected with other inequality-(re)producing practices, and how the equal social order of a dance organization is accomplished through the situated practice of mixing. In the discussion, we highlight the value of a practice theory for diversity. A practice-based theory of diversity renews the research agenda of diversity studies, forwarding post-dualistic forms of theorizing, re-conceptualizing diversity practices along the theoretical logic of practice, and conceiving diversity-related phenomena as the net-effect of social order-producing practices.
\end{abstract}

\footnotetext{
Keywords: diversity in organizations, diversity management, practice theory, equality, inequality
} 


\section{INTRODUCTION}

After almost three decades of research, diversity scholars are increasingly looking for ways to theoretically advance and rejuvenate the field. They formulate new future research directions, aiming to better understand the continuing inequality and discrimination at work (Rodriguez, Holvino, Fletcher \& Nkomo, 2016; Zanoni, Janssens, Benschop \& Nkomo, 2010), unravel the complex effects of diversity (Bell et al., 2011; Joshi, Liao \& Roh, 2011), and focus on ways to value diversity (Dwertmann, Nishii \& van Knippenberg, 2016; Shore et al., 2011). Regrettably, these recommendations tend to be formulated without much reference to ontological assumptions whereas understanding the philosophical assumptions underlying a theory is needed for being able to further develop it (Alvesson \& Sandberg, 2011; Sandberg \& Tsoukas, 2016).

Revisiting diversity research from an ontological perspective means considering how scholars are approaching the nature and basic structure of social life and social phenomena (Schatzki, 2005). It is our argument that diversity research is characterized by an underlying ontological dualism between individualism and societism - the two camps into which social theory has been divided since its conception in the mid-1800s (Schatzki, 2005). An individualist stance holds that diversity as a social phenomenon can be explained by properties of individual people or of their relations (Schatzki, 2005); in contrast, a societist stance holds that a full account of diversity requires a turn to 'extra-personal' phenomena (Schatzki, 2005) - discourse in this case. Not only has this ontological dualism stayed implicit, the dualistic nature of the ontology - partitioning concepts and treating them as opposite entities such as agency/structure, emotion/cognition and body/mind (Farjoun, 2010) - prevents in our view an effective way of understanding diversity-related phenomena in organizations. It only attends to a few central components of social reality (like cognition and discourse), neglecting other central ones (like body and materiality) (Reckwitz, 2002; 
Sandberg \& Dall'Alba, 2009). Also when aiming to include other components, the dualistic conception itself is not questioned. We thus argue the need for a relational ontology - where social phenomena are ongoingly produced and relationally constituted (Feldman \& Orlikowski, 2011) - which would help diversity research to better understand how diversityrelated phenomena like inequality, racism, discrimination, homophobia, diversity climates, inclusion and whiteness are accomplished. As practice theory is a major social theory that precisely aims to overcome dualisms (Reckwitz, 2002; Sandberg \& Dall'Alba, 2009; Sandberg \& Tsoukas, 2016), we propose to bring practice theory to diversity studies and explore its value.

The aim of the paper is to develop a domain-specific theory of practice for diversity (Sandberg \& Tsoukas, 2016) with an application to (in)equality, a critical feature of diverse organizations (Zanoni et al., 2010). First, we outline the general principles of a practice-based theory of diversity, building on the main ontological, conceptual and methodological ideas of practice theory. While there are many variations to practice theory (Gherardi, 2016; Nicolini, 2013), central is the orientation towards processes, what people do and say in action: "practicing, real-time doing and saying something in a specific place and time" (Nicolini, 2013: 219) and the consequential belief that organizational phenomena like social order, meanings and identities emerge from practices themselves (Feldman \& Orlikowski, 2011).

Second, we highlight the novelty and value of a practice lens for the understanding of (in)equality through two research examples, developed along Nicolini's theory-method package $(2013 ; 2017)$. A first example shows how a practice-based theory of diversity offers an in-depth understanding of how diversity management practices reproduce rather than change inequality in an organization. It does so by examining how a specific diversity practice (career mentoring) is connected with other inequality-(re)producing practices. A second example shows how a practice lens can contribute to our understanding of ways to value 
diversity. Starting from a social order in a dance organization that can be meaningfully understood as equal, a practice-based study can uncover how this is accomplished through situated practice. Both examples indicate how a practice lens contributes to theorizing the dynamics between diversity, (in)equality and practicing. In the discussion, we further highlight what diversity studies can gain from a practice-based perspective, emphasizing nondualistic forms of theorizing diversity, re-conceptualizing diversity practices along the theoretical logic of practice, and conceiving diversity-related phenomena as the net-effect of social order-producing practices. From this, we identify new research directions as well as the challenges that emerge from using a practice-based theory of diversity.

Whereas feminist gender studies (Bruni, Gherardi \& Poggio, 2004; West \& Zimmerman, 1987) as well as other domains in management and organization studies (MOS) like knowledge (Gherardi, 2000; Nicolini, 2011), strategy (Jarzabkowski, 2003; Vaara \& Whittington, 2012) and technology (Orlikowski, 2000; Suchman, Blomberg, Orr \& Trigg, 1999) have moved in this direction for some time now, diversity research has still to take the practice-turn (with notable exceptions: O’Leary \& Sandberg, 2017; Tatli \& Özbiligin, 2012). One possible explanation is that notions like 'practice' and 'best practice' feature already highly. Unfortunately, they are often taken for granted, reflecting what Sandberg and Tsoukas (2016: 187) call a "commonsensical" approach of practice, which is largely atheoretical. We believe however that much is to be gained for diversity studies if they consider the theoretical logic of practice. By bringing practice theory as a new theoretical lens to diversity scholars (Nkomo et al., 2016), we thus hope to capture their interest in the great promise of the practice lens which lies in explaining the complexity of diversity-related phenomena in a processual way. 
Reviewing the diversity literature, we identify two underlying ontological perspectives: individualism and societism (Schatzki, 2002; 2005), which inform how diversity and in particular (in)equality is currently understood and studied. Table 1 presents the basic differences between the two ontological stances as well as the main assumptions of practice theory that we will forward in the remainder of this paper as a promising alternative perspective.

Insert Table 1 about here

\section{The Ontologies Underlying Diversity Research: Individualism vs Societism}

To study how diversity or categories of social difference such as race, gender, class, ethnicity, sexuality, (dis)ability and nationality is manifested in organizations, diversity research has primarily opted for an individualist stance. Taking individual and interpersonal behavior as the unit of analysis (Harrison \& Klein, 2007; Harrison, Price \& Bell, 1998), scholars assume that diversity as "a social phenomenon can be explained by properties of individual people or of their relations" (Schatzki, 2005: 466). As indicated in Table 1, this individualist stance underpins social psychology theories such as social identity theory, social categorization theory and the attraction-selection-attrition framework on which diversity research heavily relies (Roberson, 2013). The dominance of psychological approaches has resulted in OB-theory based diversity research that typically highlights cognition such as cognitive bias (Konrad \& Linnehan, 1995) and stereotyping (Leslie, Mayer \& Kravitz, 2014), or motivation and traits such as need for belongingness and uniqueness (Shore et al., 2011). From this, diversity-related phenomena like inequality and discrimination but also inclusion tend to be seen as resulting from intra- and interpersonal cognitive processes. This ontological 
stance further comes with an understanding that theory implies the formulation of abstract propositions and a methodological focus on data collection through surveys, experiments and interviews.

The downside of an individualistic stance is that social phenomena are reduced to personal properties (Schatzki, 2005). Theorizing takes the form of mentalism where the social is located in the human mind (Reckwitz, 2002; Sandberg \& Dall'Alba, 2009). By relying on the aforementioned psychological theories, one foregrounds universal cognitive processes such as negative in/out group dynamics, cognitive bias and homophily patterns. Thus, in most diversity research, the "social can be found, so to speak, in the 'head' of human beings" (Reckwitz, 2002, p. 247), without attending to other central components of social reality such as body, things, discourse and structure (Sandberg \& Dall'Alba, 2009).

This downside closely resembles the critique of critical diversity scholars who argue that in order to fully understand inequality in organizations, one needs to attend to historically determined, structural power asymmetries between socio-demographic groups (Prasad, Pringle \& Konrad, 2006; Zanoni et al., 2010). As indicated in Table 1, critical scholars consequently favor an ontological societist stance holding that a full account of social phenomena requires more than 'personal' features; it requires a turn to 'extra-personal' phenomena (Schatzki, 2005). Possibilities for these extra-personal phenomena include modes of production, discourses, abstract structures, and societies (Schatzki, 2005). From among these, critical diversity scholars have primarily taken 'discourse' (Foucault, 1976) as the unit of analysis, developing discourse-theory based diversity research to understand how diversity within organizations is influenced by structural features. Discourses refer to structured collections of texts that infuse objects with particular kinds of meanings and constitute particular subject positions (Fairclough, 1995; Hardy \& Phillips, 2004).

The scholarly interest in discourse as an important extra-personal element emerged as the 
rhetorical shift from equal opportunities to 'the business case of diversity' foregrounded the capacity of language to constitute social reality. In particular, analyzing the latter, discourse scholars emphasized its capacity to obscure unequal power relations in organizations (Lorbiecki \& Jack, 2000; Prasad \& Mills, 1997); other studies have illustrated how (diversity) managers' use of certain discourses - both Grand Discourses and small discourses - regulates minority employees to subordinate positions (Dick \& Cassell, 2002; Zanoni \& Janssens, 2004). Inequality is thus understood through discourses as these latter exert power by infusing objects with particular kinds of meaning, so that certain possibilities and outcomes become more likely to be realized than others, and by endorsing certain subject positions so that certain actors can speak authoritatively (du Gay, 1996; Maguire \& Hardy, 2009). Together with discourse as unit of analysis, this ontology comes with a different understanding of theory and methodological focus. Discursive diversity scholars aim to uncover hegemonic processes within organizations and society by focusing on data analysis of publicly available texts and interview transcripts.

Yet, from this societist view, theorizing takes the form of textualism where the social is limited to the level of discourse (Reckwitz, 2002; Sandberg \& Dall'Alba, 2009). For discursive scholars, social orders have their place 'outside', on the level of signs and texts. In contrast, practice theory questions the privilege that communicative action receives over other forms of actions, and does not remain on the extra-mental and extra-corporal level of discourses, texts and symbols (Reckwitz, 2002). As Reckwitz (2002: 254) remarks, "discourse and language lose their omnipotent status" that they often receive in textual and social constructionist approaches. Instead, practice theory will re-open the realm of the social beyond discourses, texts and communication.

\section{Recommendations to Advance Diversity Research: The Dualism Maintains}


The need to overcome the dualism between an individualist and societist stance becomes even more urgent when reviewing diversity scholars' current recommendations to advance the field. Examining the latter, we note that each ontological stance seems to recognize its own potential shortfall and is implicitly acknowledging the need for the other one. Yet, by not reflecting on the ontological premise of the recommendations, the dualistic conception itself is not questioned, hereby still conceiving diversity-related phenomena like (in)equality in a limited way.

Individualists are calling for a more 'contextual' approach to capture the complexity of diversity and explain the fields' conflictual findings (Joshi \& Roh, 2009) (see Table 1). They propose to study contextual factors such as fairness systems, demographic representation or industry setting (Johns, 2006; Joshi, Liao \& Roh, 2011) as they are "seen as part of the environment that provide stimuli to individuals and are used to interpret information at work" (Shore et al., 2011: 1257). However, while an attempt is made to overcome a purely individualist and psychological stance, context is conceived as pre-given rather than emergent (Fox, 1997). It resembles a container of variables that are 'out there' while no attempts are made to unpack this box (Felski, 2011) and theorize how context may be 'in here' (Steyaert, 2016), co-constitutive with individual actions. Even more, thinking about contextual variables in this way, a call for multi-level research (Dwertmann et al., 2016; Joshi et al., 2011) is made which introduces a new dualism: the micro-macro divide where, despite all research strategies to study the interstices of multiple levels, individuals remain the central unit of analysis. Also scholars within intersectionality research, who increasingly call to focus on "the interplay of subjectivities, micro-level encounters, structures and institutional arrangements", forward multi-level and cross-level research (Rodriguez et al., 2016: 204), still conceiving the individual and structure as a priori given, separate entities. 
Societists are calling for agentic strategies (of minority individuals) that are capable of dealing with the discursive structural constraints (see Table 1). Acknowledging that a discursive approach entails the danger of determinism (Hardy \& Phillips, 2004), diversity scholars increasingly have brought human action into their discursive analyses to nuance the power of discourse. Investigating minorities and diversity practitioners' active engagement with discourses of diversity, they highlight discursive struggle and show how discourses, while powerful, never fully determine the meaning of diversity at the workplace (e.g. Ahmed, 2007; Essers \& Benschop, 2007; Van Laer \& Janssens, 2017). Yet, while agency is emphasized, its conception tends to be limited to discursive ways of resisting like rhetorical strategies. Just as individualists, societists hold on to their unit of analysis - discourse - to then conceive the other pole in discursive terms. Non-discursive components like the embodied and material nature of agency or emotions tend not to be part of the investigation although their relevance is increasingly acknowledged in debates on the relationship between discourse and materiality (Hardy \& Thomas, 2015; Orlikowski \& Scott, 2015; Putnam, 2015).

Our argument is that, for diversity research to really advance and to better understand (in)equality (and other diversity-related phenomena), a different - relational - ontology is needed that allows for theorizing the overcoming of the various dualisms such as agency/structure, subject/object, mind/body, inner/outer, emotion/cognition. Practice theory offers such line of reasoning, which we will explain in the next section.

\section{PRACTICE THEORY: ONTOLOGICAL, CONCEPTUAL AND METHODOLOGICAL PREMISES}

Practice theory is "not a full-blown grand theory" (Reckwitz, 2002: 257) but consists of a rather broad family of theoretical approaches (Nicolini, 2013; Sandberg \& Tsoukas, 2016) that adhere to a post-dualistic ontology, sharing the assumption that social reality is 
fundamentally made up of practices (Nicolini, 2013) and emphasizing each in their own way a coherent theory-method package. We sketch here the main set of practice theory's ideas ontological, conceptual and methodological - as well as its internal variety related to the field's evolution (Gherardi, 2016).

\section{The Relational Ontology of Practice Theories}

Practice theories start with an ontological reflection to overcome dualities ingrained in current social theory and to move to a post-dualistic ontology, which is increasingly called 'a relational ontology' (Gherardi, 2016; 2017; Nicolini, 2009a; Nicolini \& Monteiro, 2017). They all question the cognitive, rationalist perspective of Western intellectual tradition and critique its entitative, disconnected and dualistic logic of scientific rationality (Sandberg \& Tsoukas, 2011). Instead, practice theories share the idea that phenomena are always conceived in relation to each other, produced through a process of mutual constitution. The recognition of the practice as a post-dual and relational concept is an ontological choice, offering a remedy for the problems left unresolved by mentalism and textualism (Reckwitz, 2002) and their ways of describing a research object in terms of unnecessary dualisms like actor/structure, body/mind or theory/action (Nicolini, 2017).

Practice theories differ though in how they specify the relational nature of practice, depending on the specific duality and philosophical resources. The so-called 'first generation' of practice theories - such as those by Bourdieu and Giddens - are rooted in a number of philosophical traditions, including the work of Marx, Heidegger, Wittgenstein, and the North American pragmatist tradition (Nicolini, 2013; Sandberg \& Dall'Alba, 2009). For instance, Anthony Giddens (1976), not only influenced by Heidegger's existential ontology but also Garfinkel's (1967) ethnomethodology (Gherardi, 2018), is well-known for theorizing the inherent recursiveness between agency and structure through his notion of structuration 
(Sandberg \& Tsoukas, 2016).

‘Second-generation’ practice theorists such as Schatzki (2002), Nicolini (2013) and Gherardi (2006) have further developed practice theory, both in terms of ontological and social-theoretical articulation. The philosopher Theodore Schatzki (1996; 2001; 2002; 2005) draws upon Heidegger's existential ontology and Wittgenstein's later philosophy to theorize the circularity and co-emergence between human affairs and the contexts in which they occur, proposing the notion of 'site ontology'. Davide Nicolini $(2011$; 2017) further develops this notion of site by turning to relational sociology (Emirbayer, 1997) and Latour's (2005) actor network theory. He emphasizes a processual and site-based ontology of practice theory and follows a posthuman approach, granting equal agency to material things as necessary and active elements of human practice. Also Silvia Gherardi $(2015 ; 2016 ; 2018)$ takes a posthumanist approach, which she further develops into an onto-epistemology of relational materialism. Drawing upon feminist philosophy and theory by Butler (1993), Haraway (1991) and Barad (2003), she theorizes the connections between matter, language and bodies, proposing the notion of sociomateriality.

\section{The Conceptual Understanding of Practice}

As practice has ontological primacy, the basic unit of analysis for understanding social and organizational phenomena are practices and their nexus with other practices (Nicolini, 2013). Practice theory "locates the social in 'practices"” (Sandberg \& Dall'Alba, 2009: 1352): practices come first and if one wants to understand social life, one needs to turn to the accomplishment of real-time practices. Think for example of the various everyday practices such as greeting, parenting and driving or work-related practices such as teaching, nursing and managing that make up social life (Sandberg \& Tsoukas, 2016).

While different definitions of a practice exist, a practice is conceived as simultaneously 
discursive, embodied and material (Nicolini, 2017; Sandberg \& Tsoukas, 2016). Practice theory emphasizes that a practice cannot be reduced to only words and foregrounds as well the role of the body and artefacts in all human affairs. Think for example of how the practice of teaching is embodied - standing firm, speaking aloud - and how the feminized body may not always be tuned to such practice of teaching which paradoxically is seen as disembodied rationality. Also material things are inherently part of a practice theory and therefore a practice study attends to how tools, objects and artifacts contribute to how the practice is carried out and made possible (Orlikowski, 2000). Teaching a class, investigating accidents, cooking a meal are always accomplished with, and amid, material things (Nicolini, 2013). Important is that tools, discourse and our bodies are knotted together in how practice is accomplished.

Further, a practice never comes in isolation but is related to other practices. Teaching for instance depends on its alignment with other practices such as enrolling students, opening the school and keeping it clean (Nicolini \& Monteiro, 2017). The social world thus is a vast nexus of practices, also referred to as knots, networks, sites, configurations, assemblages and textures (Czarniaswka, 2007; Gherardi, 2006; Latour, 2005; Nicolini, 2011), that creates a particular social order. Important here is that power, conflict and politics are constitutive elements of social reality (Nicolini, 2013). As Gherardi (2016: 685) remarks, ordering social life through practices is "achieved within a plurality of discourses, unequal power relations among stakeholders, and through the redistribution of power". Practices are thus never neutral activities, but serve certain interests at the expense of others (Nicolini, 2013) and fit differently into the system (Ortner, 1984), impacting the distribution of power and privileges.

\section{Methodological Orientation of Practice Theory}


Together with a distinct ontological commitment and conceptual understanding of practice, the methodological element takes a central place in practice theory (Nicolini, 2017). In fact, reducing it to pure theory would be contradictory as practice theory should be conceived as "the pragmatic effort to re-specify the study and re-presentation of social phenomena in terms of networks, assemblages and textures of mediated practices" (Nicolini, 2017: 19; our italics). It requires an empirical study that is "ethnographic in its sensibility" (Miettinen, SamraFredericks \& Yanow, 2009: 1312), a witnessing of real-time practicing which allows scholars to understand how the social phenomenon under study transpires amid and through practices. Studying the social in this way further qualifies the nature and role of theory. Whereas theorizing on diversity has until now been understood as either formulating abstract notions and generalizable propositions, or the uncovering of the hegemonic nature of diversity discourses (see Table 1), practice theory emphasizes that "good science should be articulative" (Nicolini, 2017: 30). This does not mean that a practice lens is simply an invitation for empirical cases that provide long and close-up micro descriptions, rather, it is a mode of theorizing where social phenomena are re-specified in terms of practice and their associations, creating “enlightening texts" (Nicolini, 2017: 24).

As a package of theory, method and vocabulary (Gherardi, 2012; Nicolini, 2013), practice theory thus also attends to how practice-based studies can be conducted. To realize the idea of internal coherence, Nicolini (2017; see also Nicolini \& Monteiro, 2017) has developed four research strategies that are processual in nature. These ways are 1) a situational strategy focusing on the practice itself through studying "the concerted accomplishment of orderly scenes of action" (p. 26); 2) a configurational strategy - focusing on the connections in space or "how concerted accomplishments and performances hang together to form constellations or larger assemblages" (p. 29); 3) a genealogic strategy - attending to time or "how individual practices emerge and disappear" (p. 26); and 4) a conflict-sensitive strategy - focusing on the 
tensions among practices by attending to "the co-evolution, conflict and interference of two or more practices" (p. 30). While each research strategy has its own focus, they all contribute to the effort of re-specifying a social phenomenon.

\section{A PRACTICE-BASED THEORY OF DIVERSITY}

From the above main set of ideas, we forward five principles of a practice-based theory of diversity that guide diversity scholars in studying and understanding the complexity of diversity in a novel way. Table 2 captures the five principles and their key description.

Insert Table 2 about here

Post-dualistic ontological articulation. A first principle is oriented at a post-dualistic ontological articulation. A practice-based theory of diversity follows a relational ontology, conceiving diversity as a social phenomenon that is relationally constituted. It rejects the predominant view that the social world can be nicely divided into dualisms such as agency/structure, mind/body and social/material (Reckwitz, 2002) and, instead, orients towards the mutually constituted nature of social life. Theorizing diversity implies that researchers adopt a post-dualistic ontology to overcome traditional dichotomies and to emphasize the relationality between body, mind, things, knowledge, discourse, structure and agent, coming together in a 'practice' (Nicolini, 2013; Reckwitz, 2002). Such ontological reorientation can be realized through different relational ontologies as discussed in the previous section (see also Sandberg and Dall'Alba, 2009). In the remainder of this paper, we will follow Nicolini's (2011) understanding of a processual, site-based ontology to emphasize the co-emergence of a diversity practice and its site, and Gherardi's $(2016 ; 2018)$ relational- 
materialist ontology to emphasize the entanglement of meaning and matter in a diversity practice.

Unit of analysis is a practice. Second, the study of the social life in diverse organizations starts with practice. As diversity research no longer assumes that the social is located in the human mind or in texts but in practices, the unit of analysis shifts (Feldman \& Orlikowski, 2011; Nicolini, 2013). Instead of studying properties of minority and majority individuals, or diversity-related discourses, diversity scholars orient to practice to understand the complexities associated with diversity in organizations. Importantly, the practices that produce social life in diverse organizations are not only diversity management practices but all other management practices such as decision making practices, strategy making practices, leadership practices, team work practices that produce the social order of a diverse organization. Taking a practice lens transforms diversity scholars' view on diversity practices, broadening it to all social order-producing activities within the realm of diversity.

Entanglement of body, materiality and discourse. Understanding a practice further requires the study of how this practice is accomplished through the connection between bodies, tools and artefacts, and discursive resources. Practices that (re)produce a particular social order in a diverse organization are inscribed in the body, through learning and repeated injunctions, being partially routinized, partially improvised (Nicolini \& Monteiro, 2017; Reckwitz, 2002). Further, these practices are inherently material in nature as, within a practice, tools and artefacts shape their meaning (Gherardi, 2016). And finally, discursive practices or language in action are central to the accomplishment of a practice, without reducing the latter purely to discourses (Nicolini, 2013). Looking at the embodied, material and discursive entanglement and its accomplishment is thus required to understand how a diversity practice becomes a social order-producing practice.

Practices are connected in space and time. Fourth, a practice-based theory of diversity 
focuses on connections in space and time. As a practice is always situated in space and time, with 'connectnedness in action' (Gherardi, 2006), a practice-based diversity study brings to the fore the wider site or texture a diversity practice is part of (Nicolini \& Monteiro, 2017). By tracing these connections and its endless series of relationships which continually move into each other (Gherardi, 2017), it will become visible how diversity-related phenomena like inequality and discrimination are locked into a nexus of practices but also how a positive diversity climate or inclusion can emerge from intertwined practices. This focus on connections is in line with the emerging critique within diversity research that the focus on standalone diversity practices is incompatible with organizations relying "upon a group, or bundle, of complementary and mutually reinforcing practices to achieve positive diversity outcomes" (Roberson, 2013: 467).

Explanations are grounded in what is empirically observable. A final principle is to understand diversity-related phenomena through real-time accomplishment of practices. This requires a processual focus, committed to an observational orientation and the adoption of methods that allow an appreciation of practice as it happens (Nicolini, 2013: 14). Aiming to be articulative, diversity scholars need to go to the real-time practicing, in the midst of the action through ethnographic observation (Nicolini, 2013), shadowing (Bruni et al., 2004), and participative research. These observational methods can possibly be complemented by archival data and adapted forms of interviews, such as the interview to the double - a projective technique that aims to capture the actual (not people's versions) doings and sayings by asking interviewees to provide the necessary detailed instructions to a double who will show up the next day at work (Nicolini, 2009b).

Jointly, these five principles form a domain-specific practice theory of diversity that promises a better understanding of social life in diverse organizations through practices and its connections. Importantly, we remark that the object of a practice-based theory of diversity 
is not diversity practices as such, but diversity-related phenomena such as inequality, discrimination, gender relations or inclusion that are re-specified in terms of practices (Nicolini, 2017). A practice-based theory of diversity is thus a mode of theorizing that is focused on re-articulation, a theoretical practice that keeps close to the empirical work of the diversity researcher in order to allow "the phenomenon to bite back" (Nicolini, 2017, p 25). Such conception of theory consequently asks from diversity scholars openness to explore less positivistic, functionalists orientations as well as to move beyond purely discursive analyses.

\section{TWO RESEARCH EXAMPLES: RE-SPECIFYING (IN)EQUALITY IN AN}

\section{ORGANIZATION}

Within the logic of practice theory, theorizing cannot be disconnected from what is empirically observable (Nicolini, 2013; 2017). Following this idea, we discuss two research examples to show the value of a practice lens for diversity research. The first example takes on the crucial question of how to understand the persistent inequality in a diverse organization, despite the implementation of a formal, traditional diversity management practice (Janssens \& Zanoni, 2014; Kalev, Dobbin \& Kelly, 2006). The second example starts from a social order of a diverse organization, which can be meaningfully understood as equal, to then investigate how equality is accomplished through situated practice. Both examples follow the principles of a practice-based theory of diversity to develop a better understanding of resp. inequality and equality in the organizations under study.

\section{The Re-Production of Inequality through the Practice of Career Mentoring}

In this first example, we show how a practice-based theory of diversity informs research on persistent inequality through a fictionally developed example on career mentoring in a technological organization, integrating hypothetically the results of various studies on career 
mentoring (Blake-Beard, 1999; Ragins, 1997; Thomas, 1989). Career mentoring refers to a developmental relationship through which a more experienced individual (the mentor) shares skills and information in an effort to support another individual's (the protégé's) personal and professional growth, which is supposed to reduce discrimination and create a more equitable workplace (Blake-Beard, Kram \& Murrell, 2017; Dawson, Thomas \& Goren, 2013). Imagine that this practice was two years ago introduced in an organization in the technological sector to advance the career mobility of black women and men, yet without any major results.

Site-based ontology. Following the first principle of explicitly articulating the ontological premise, our example follows a 'relationist ontology', as developed by Nicolini (2011) in his use of the concept of 'site'. This notion brings "to the fore the wider relational scene of which the phenomenon is part" (Nicolini, 2011: 604), depicting social life "in relational terms (not levels) as being composed by and transpiring through, a bundle or network of practices (Nicolini, 2013: 8). It emphasizes to understand a particular phenomenon as and via interrelated practice-arrangement bundles, seeing the phenomenon and its conditions as always co-evolving and mutually implicated. This ontological choice aligns well with the nature of careers, being dynamic, boundaryless and multi-directional trajectories of movements (Sullivan \& Arthur, 2006).

Observing career mentoring in situ. Aiming to understand how career mentoring is related to inequality, the empirical study takes practice as the unit of analysis. It would start by taking a situational research strategy, zooming in on the practice and observing a series of career mentoring sessions (Nicolini, 2009a; 2017) to see how career mentoring is accomplished in an embodied, material and discursive way. Employing insights from previous studies (Giscombe, 2017; Ragins, 1997), we imagine that a diversity scholar possibly would observe that it are primarily white men mentoring black women and men, and that the mentoring sessions take place in the mentors' high-status offices. She might further notice how white men, in an 
impersonal manner, with stiff bodily gestures and a formal, loud tone of voice, limit their mentoring to fixing 'their problems', giving advice in terms of being more visible or taking on a line assignment instead of a staff assignment (Blake-Beard, 1999; Ragins \& Cotton, 1999), while not engaging in the psychosocial function of mentoring like acceptance, confirmation and friendship (Kram, 1985) as well as not discussing issues that are related to mentees' race (Thomas, 1993; 2001). The diversity scholar might further observe how also black women, nervously sitting at the other side of the impressive office desk, refrain from establishing a warm and open relation, later explaining in an interview how they aim to keep a distance from white men, being afraid of 'being seen with white men', going back to historical dynamics of slavery where white men appropriated black women (Thomas, 1989) and 'not being a competent professional' (Bell, 1990). Most of the embodied doings and sayings of career mentoring would thus be hierarchical, racialized and male-gendered, with minorities at the receiving end.

Tracing connections. Having a first understanding of the situated practicing of career mentoring, the diversity scholar then would take a configurational research strategy, 'zooming out' to look for other practices and performances that are connected with career mentoring. Tracing the configuration of practices in which career mentoring is 'sited', one can see "the connection between the here-and-now of the situated practicing and the elsewhere-and-then of other practices" (Nicolini, 2009a: 1392). For example, the researcher might follow material artefacts (Latour, 2005; Nicolini, 2009b) such as the career mentoring reports and observe committee meetings where these reports are discussed and promotions are decided. There, she might for instance notice how black employees still face a tough time. White male employees would be promoted upon simple recommendation of their supervisor whereas promotion of blacks was heavily debated. Committee members would for example express concerns that a black male candidate did not volunteer enough for challenging assignments, questioning the 
impact of career mentoring, or stating that he was not being 'tough enough'. Only when the candidacy of a black person was discussed ahead of time, in personal conversations among supervisors or mentors, was there a chance on promotion (Thomas, 1989). In addition, she might follow women and minority employees to their project team, observing there the team interactions. In line with feminist technology research (Faulkner, 2001; Kelan, 2007), she would notice how aggressive humor is used to distance the few women present in the team and how men are making the key decisions on technology development. Also the leadership of these teams would highlight women's 'otherness', asking women to take minutes of the meeting and excluding them in discussions. In this organization, career mentoring is then locked into a larger configuration of other inequality-producing practices like decision making and leadership practices.

Theorizing the reproduction of inequality. Taken together, this study explains how, in this organization, the enduring unequal position of black women and men is the result of a particular kind of accomplishment of career mentoring, connected to decision making and leadership practices that together co-constitute a 'site' of a hierarchical, masculine and racialized realm. Taking a practice lens, one can understand how the set of mediated, embodied doings and sayings of career mentoring that produce majority mentors as competent and worthy of privileged positions versus minority mentees as incompetent other belongs to a nexus of practices that in a circular way co-accomplish each other, keeping inequality in existence.

This explanation of inequality implies a very different view on the question whether and how a diversity management practice like career mentoring is effective or not. It moves away from relating career mentoring to properties of individuals and of their relations, highlighting skills of mentors and the quality of the mentoring relationship (Dawson et al., 2013; Ragins, Cotton \& Miller, 2000). Instead, a practice lens makes the reinforcing mechanisms of related 
practices visible. Career mentoring is a situated and interconnected practice and to understand the effects of career mentoring, diversity scholars would trace its site or context to which this practice is inherently tied; the practice of career mentoring can only be studied relationally, and thus "only be understood as a part of a nexus of connections" (Nicolini, 2013: 229). Identifying such nexus of connections then is crucial to see through the dynamics of inequality-producing practices. It further may offer diversity practitioners inspiration to stop the reproduction cycle by bringing in new activities that would change the connections between the practices, making another kind of social order possible.

\section{Uncovering a Situated Practice through Studying an Equal Social Order}

Our second example takes a different point of departure. Rather than examining how a diversity practice reproduces inequality, it starts from a social order that can be meaningfully understood as equal, to then study how this order is accomplished through a nexus of daily actions and activities. This example identifies a different diversity practice - the practice of mixing - that we uncovered in the internationally-renowned dance company Ultima Vez which, since its start more than 30 years ago, is experimenting with all kinds of differences. In contrast to most organizations in the creative industries (Eikhof, 2017; Finkel, Jones, Sang \& Russell, 2017), this organization does not limit professional dance to an elite group of young, ideal-bodied performers. It works with men and women from all ages, different abilities (blind, down syndrome, physical disability), race, ethnicities and languages. Even more, located in Molenbeek, one of the most impoverished neighborhood of Brussels, it aims to actively engage with the local challenges of inequality and discrimination. While based on own empirical work of two dance productions choreographed by Seppe Baeyens, the following is not meant as an empirical case but as an illustration to show the value of taking a practice lens in uncovering a situated practice that accomplishes an equal social order. 
Ontology of relational materialism. This study is inspired by the onto-epistemology of relational materialism, which assumes an "ecological model in which agency is distributed between human and non-humans and in which sociomaterial relationships can be subjected to inquiry” (Gherardi, 2015: 684). The term 'sociomateriality', derived from Barad's (2003) feminist onto-epistemology, focuses on the "generative entanglement" of meaning and matter, the social and the technological which are inseparable (Gherardi, 2017: 40). Such ontological focus on the sociomateriality of practice aligns well with the nature of a dance performance, as the latter is enacted through the entanglement of ideas, bodies, spaces, music, costumes and aesthetic styles. Also the discursive and non-discursive are seen as symmetrical (Gherardi, 2016) which is again relevant for dance, a (non-verbal) language of its own that rebalances embodied sayings and doings. The ontological commitment thus is to analyze how "within a practice, bodies, matter and discourses are expressions of the same sociomaterial world" (Gherardi, 2017: 42).

Observing actions in situ. Identifying an emerging practice within an equal social order asks for a situational strategy, focusing "on the concerted accomplishment of orderly scenes of action" (Nicolini, 2017: 27) and tracing their bodily, material and discursive components. Guided by the idea that "studying a new or unfamiliar practice without familiarizing ourselves with it would be logically impossible” (Nicolini, 2017: 27), one starts with 'zooming in' on the here-and-now of the situated practicing to witness 'practicing', its doings and sayings in a specific time and place. In this study, we started with observing open dance workshops and rehearsals during summer holidays, witnessing a very diverse range of participants of all ages, abilities, gender, and ethnicity engaged in movement exercises. We noticed here how their activity of rehearsing altered the concept of embodiment that usually figures in the world of artistic dance. While lifting a person is a core element of dance, it typically assumes that everyone is equally able to do this - even if, for instance, women never lift men in classical 
ballet. In this case, small-group combinations were created so that also a male adult could be carried by children, supporting a new imagination that 'everyone can be(come) a dancer', or a woman in a wheelchair initiated a group dance inviting other participants to follow, imitate and contrast her movements.

Tracing connections. Informed by what Nicolini (2017: 101) calls relational or connected situationalism, the basic unit of observation and analysis is "not a single scene of action, but rather a chain, sequence or combination of performances plus their relationships - what keeps them connected in space and time". Therefore, we traced connections by zooming out to other activities, outside the dance rehearsal and performance spaces. For instance, we noticed the importance of the activity of inviting, continuously contacting not-for profit organizations and schools and convincing them to encourage their members to take part in dance. The involvement of a network of local partners implied also establishing and maintaining socialmaterial arrangements. For example, the care home of the dancers with down syndrome had to plan transportation and (in the beginning) accompany them during the workshop, or a buddy system was needed where each performer was assigned to care for another colleague during meals, dress-rehearsals, or restroom breaks.

Additionally, we noticed how the activity of rehearsing in the case of a diverse group not only altered the concept of embodiment but also enacted a new 'mix' of the discursive and non-discursive. Observing the feedback session after a general repetition, we noted how the presence of the blind dancer re-ordered the balance between sayings and doings. Not being able to take notes of the suggested improvements by the choreographer, he engaged in repeated paraphrasing and asking questions - insisting the choreographer to be as precise as possible, which also benefited the other dancers.

Finally, we noted how the sociomateriality of the performance and its creation was altered. For example, the safety and orientation of the blind dancer required the spanning of dark 
ropes over the scene. Or, in the case of a dancer with down syndrome who regulated his anxieties through focusing on a few straws, the straws became integrated in the performance: in the final scene, the dancer hands over the straws to a member of the audience and then goes into a dance of trance, inviting his colleague dancers and audience members to join him in a very moving collective apotheosis. Thus, by tracing a chain of interrelated actions, we could understand how the activities of rehearsing, inviting and performing bundled together into a practice of 'mixing', enabling the accomplishment of an equal social order.

Theorizing the accomplishment of equality. Together, this situational orientation of focusing on a variety of local accomplishments was helpful in articulating a range of activities as an unfamiliar diversity practice - which we called here through "reverse-engineering" (Nicolini, 2017: 28) 'mixing'. In our theoretical understanding, we propose that the effect of the practice of mixing on equality is enabled through the heterogeneous mixture of discursive, bodily and material forces that come together in a specific configuration which changes normativities with regard to age, ability or ethnicity (Riach, Rumens \& Taylor, 2014). Including a blind dancer, mentally disabled person or elder woman in a dance performance is not a matter of adapting the dancing practice to their 'weaknesses' and thus attaching these differences as individual or structural features to them. Instead, diverse dancing is enabled through creating new connections between their bodies, other dancers and the affectivematerial dance space, so that the dance performance itself is altered and colored by the mix of differences. The practice of mixing thus contributes to understanding how inclusion can be accomplished where the importance of high belongingness and high uniqueness theoretically has been emphasized (Shore et al., 2011). However, in contrast to the model of Shore et al. (2011), these features are not seen as individual needs, but are ingrained in the embodied, habitual and relational practice of mixing where the unique differences (Ostendorp \& Steyaert, 2009) become incorporated and unfolded in the activities of the group. 
Therefore, this coming-together of differences in a "network of connections-in-action" (Gherardi, 2016: 685) can be called a "choreography of becomings", as suggested by Gherardi (2017: 44). The ontological stance of sociomateriality thus offers diversity studies a powerful lens to see how intertwined normativities with respect to age, disability, ethnicity or sexuality can become interrupted through ways in which the discursive, bodily and material dimensions within a practice are entangled. The invitation to diversity studies is thus to appreciate 'practicing diversity' as a bodily, material and discursive choreography.

\section{DISCUSSION: THE VALUE OF PRACTICE THEORY FOR DIVERSITY}

While several MOS domains have already invested in practice-theory based research, diversity research has yet to take 'the practice turn'. In this paper, we have developed a practice-based theory of diversity and applied it to (in)equality, showing how a practice lens understands and studies this phenomenon differently. We now highlight three main gains of a practice-based theory for diversity, forwarding theorizing within a post-dualistic realm and reconceptualizing diversity practices as well as diversity-related phenomena.

\section{Launching Diversity Theory into a Post-dualistic Realm through a Relational Ontology}

Throughout this paper, we have emphasized the importance of ontological reflection for retheorizing diversity in organizations. Practice theory comes with its own "ontological commitments" (Watson, 2017: 169), necessitating a reconsideration of philosophical assumptions regarding core notions of social life such as agency, body, materiality and structure.

Taking the practice turn in diversity research thus implies a fundamental alternative view on social reality where, in contrast to the traditional structural-mechanistic and functionalsystemic views, a diverse organization needs to be thought of as a "fluid scene that unfolds in 
front of us in terms of multiple practices carried out at the same time" (Nicolini, 2013: 2). At the center of analysis is no longer a static entity - such as in individualism (persons) or societism (structures) but the foregrounding of activity in the creation and continuation of all aspects of diverse organizational life. Therefore, any (reified) dualism would be dismantled, such as for instance the dualistic conceptualization of micro/macro level, a principal duality in the diversity literature. Instead of treating the macro as a form of 'externality' that is detached from individual or organizational action and which afterwards needs to be bridged, diversity research would focus on the recursive relationship between specific instances of situated action and the diverse organization in which the action takes place (Feldman \& Orlikowski, 2011). It would understand micro and macro as processually and recursively produced through practices, never 'outside' practice. Or as Schatzki (2016: 28) points out: "practice theory as social ontology holds that the realm of the social is entirely laid out on a single level (or rather, on no level)". A practice-based theory of diversity thus promises the overcoming of ‘unhelpful dualisms' (Feldman \& Orlikowski, 2011; Sandberg \& Tsoukas, 2016), which currently infuse most diversity research.

Commitment to a relational ontology then directs diversity research towards studying recursive relations, hereby relying on theories within a post-dualistic realm. At the same time though, the move to a post-dualistic realm goes against diversity research's theoretical habitus to install a priori distinctions between entities and levels. Thus, a crucial challenge (see Table 1) will be the development of a vocabulary that adequately expresses the processual and relational nature of practice theory's conceptions (Gherardi, 2016), a new relational language and logic that allow scholars to transcend dualistic divisions and levels and to express the recurrent nature of everyday practices (Feldman \& Orlikowski, 2011; Miettinen et al., 2009). This is an extra-ordinary challenge, as diversity scholars - like other MOS scholars - are familiar to deal with entities, rather than performances (Nicolini \& Monteiro, 2017). 
In our research examples, we have engaged with the notion of 'site' to refer to the recursive relationship between a social phenomenon and the context in which it transpires, and with 'sociomateriality' to refer to the inseparability of meaning and matter, the social and the technological. But many other vocabularies from practice theory can inspire future research to adequately express the processual and non-dualistic orientation of 'practicing diversity'. To start with the most obvious example: even if 'practice' is a common sense word, we should not forget that it is proposed as a different, relational concept to overcome in 'one' notion the dual referencing to individuals and systems, or to agency and structures.

Other processual notions, that concern the central role of bodies in practice, are for instance 'entwinement' (Sandberg \& Dall'Alba, 2009) and 'embodiment (Gherardi, 2018). Entwinement, referring to Merleau-Ponty's notion of the 'lived body', may help diversity scholars to overcome the mind-body dualism and study how the work of diversity practitioners is an entwinement between particular activities, knowledge, equipment and relations with others. Embodiment is proposed by Gherardi (2018) to express "how the nature/culture division is blurred in the materiality of bodies encountering a material-semiotic environment" and may infuse future diversity research to incorporate the sensual and bodily experience of practice. Diversity scholars may also turn to the work by Pierre Bourdieu (1977; 1990) who has developed maybe one of the most inventive vocabularies to overcome the objectivist/subjectivist dualism. Reflecting on how to theorize practice theory in a processual way, Bourdieu spoke of the need to attend to 'dialectical' relations in order to "[c]onstruct the theory of practice, or, more precisely, the theory of the mode of generation of practices, which is the precondition for establishing an experimental science of the dialectic of the internalization of the externality and the externalization of internality, or, more simply of incorporation and objectification" (1977: 72). This theoretical task has resulted in a refined series of intertwined notions - such as habitus, field, capital, doxa, hysteresis, conatus, and 
reflexivity (Grenfell, 2012), which not only makes Bourdieu's practice theory complex but often misappropriated (Townley, 2014), and, also, underrepresented in diversity studies (Tatli, 2011; Tatli \& Özbilgin, 2012).

\section{Re-Conceptualizing Diversity Practice along the Theoretical Logic of Practice}

Currently, diversity scholarship tends to approach the notion of practice in an a-theoretical, commonsensical way (Sandberg \& Tsoukas, 2016). It equates diversity practices with particular types of practices - selection, training, mentoring, networking -, and when defined, they are understood in terms of their purpose - "formalized organizational system, process, or practice developed and implemented for the purpose of effectively managing a diverse workforce" (Yang \& Konrad, 2011: 7). From a practice lens though, diversity research would aim to capture the theoretical logic of practice, no longer glossing over the meaning of practice or reducing it to simply what people do (Sandberg \& Tsoukas, 2016).

Adopting this theoretical logic, we endorse the idea that a diversity practice consists of a set of real-time doings and sayings, mediated by the way in which discourse, materiality and our bodies are entangled (Nicolini, 2017). Such conception opens up a much richer understanding of how things actually happen, attending to crucial aspects of activity, performance and work that has been overlooked by diversity research. It implies that the focus is no longer on the substance of a practice but on a way of selecting, a way of training, a way of career mentoring. The strength of a theoretical logic of practice then resides, as Nicolini \& Monteiro (2017: 123) nicely put it "in grounding explanations in what is empirically observable, patiently tracing back phenomena to arrangements of concrete elements that produce the state of affairs under investigation - instead of analytically hiding in vague notions or mechanisms".

The potential reward for diversity research is not only more interesting and effective ways to understand how a diversity practice is accomplished, but also new ways of connecting 
research with practice (Sandberg \& Tsoukas, 2011). Practice theory puts forward a rationale of a different ontological-epistemological stance (Gherardi, 2016; Sandberg \& Tsoukas, 2011): what is most relevant for practice and thus, what is most 'practical' for diversity practitioners is to understand their everyday practices through relating it to the concept of 'social practice'. Bringing in concrete examples and thick representations of practices may in fact help practitioners to see through conventional ways of doing and explore new ways of practicing (Nicolini \& Monteiro, 2017).

The theoretical conception of practice opens up a range of new research directions. Until now, diversity research has not paid much attention to the elements of embodiment and materiality. Encouragingly, studies start to explore the embodied nature of diversity, considering for example inclusion through the lens of embodied ethics (Tyler, 2018), and, under the impulse of performative studies of gender and sexuality (Butler, 1993), bring in materiality such as space to explore the (re)construction of inequality regimes (Wasserman \& Frenkel, 2015) and dominant gender norms (Tyler \& Cohen, 2010). Much more though can be done to fully understand how practicing diversity is a situated, embodied activity and how this activity transpires and travels amidst material arrangements. Importantly is that future research would consider not only the different elements that are part of a practice but also, and crucially, the entanglement of those embodied, material and discursive resources. As our example of the situated practice of mixing indicates, it is through focusing on the particular socio-material entanglement - how these elements hang together and prevent or reproduce normativities - that diversity scholars will be able to better understand how a particular practice accomplishes a particular social order.

Further, a theoretically informed understanding of practice may especially be relevant to uncover practices that value diversity - an increasingly evolving research stream (Dwertmann et al., 2016; Shore et al., 2011). We envision that future research may benefit in particular by 
looking for cases where new bodily, affective and discursive choreographies are expected to be found and that accomplish equality and inclusion in new ways. We thus encourage diversity scholars to find positive, affirmative examples where such situated practices can be uncovered. We can imagine that inspiring everyday practices of managing diversity can be found in 'caring and compassionate organizations' (Rynes et al., 2012) or 'organizations with purpose' (Hollensbe et al., 2014) as well as in particular industries like the creative industries in our illustration or in social movements that value principles which are also relevant to diversity research such as plurality and human dignity.

While the theoretical logic of practice thus promises better insights into how diversity is accomplished, bringing it also closer to a practice logic, the challenge (see Table 1) is to not fall into "practice architecturism" (Nicolini, 2017: 32). Observing the social life of diversity, scholars need to be aware that several practices happen at the same time: "empirically, we always encounter multiplicities or arrays of activities" (Nicolini, 2017: 27). Scenes of actions are nexuses where several practices intersect (Schatzki, 2005; Scollon, 2001) which means that empirical researchers are exposed to a variety of actions belonging to several distinct practices rather than a single one. This complexity raises then the challenge for diversity scholars to find out which practices are relevant before they can proceed to study them in detail (Nicolini \& Monteiro, 2017). Further, scholars need to be careful to not reify practices when analyzing the empirical material. Nicolini (2017) reminds scholars that the theorization in practice-based research is re-articulating social phenomena, not the practice itself. So, when studying diversity practices, its connections and effects, diversity scholars should not fall into the trap of a form of 'practice architecturism' (Nicolini, 2017) where the goal is to create abstract processes rather than understanding how practitioners do it for real. Similar, aiming to identify situated practices that accomplish a more equal social order, the focus should be on the localized performances, not on the practice as an entity. 


\section{Re-Conceptualizing Diversity-Related Phenomena as Effects of Order-Producing Practices}

Finally, a practice-based theory of diversity conceives diversity-related phenomena differently. As our two research examples showed, inequality and equality need to be seen as the result of net-effects produced and reproduced through practices and their associations. They are a particular social order in a diverse organization, being the result of meaning making, identity-forming and order-producing practices (Chia \& Holt, 2008; Nicolini, 2013). Such practice-based re-conceptualization is not only applicable to (in)equality but also to other diversity-related phenomena. Racism, discrimination, homophobia, inclusion, diversity climate, or whiteness can be similarly seen as seemingly stable features of a social organizational order, transpiring amidst and through practices and their associations. In general, we forward that diversity-related phenomena are to be re-conceptualized as "the result of vast action nets kept together by the unremitting work of both human and nonhuman entities (Czarniawska, 2004)” (Nicolini \& Monteiro, 2017: 121).

Such reconceptualization requires diversity studies to uncover those practices and their associations that produce the effect under study. Or, as Bourdieu (1977:43) indicated: uncovering the 'structuring structures' (see Poggio, 2006). The four research strategies as developed by Nicolini (2017) might be helpful here, as each strategy has its own focus in respecifying the phenomenon under study. Diversity studies interested in uncovering the persistence of a social order may best turn to a configurational strategy as the latter investigates how practices are connected to form a bundle, which keeps the social order locked in. A genealogic strategy is very complementary in this regard and allows diversity scholars to investigate the historical emergence and stabilization of practice(s) and bundle(s). Diversity studies interested in the concrete accomplishment of a situated practice will turn to a 
situational strategy. This is particularly relevant when aiming to understand in-depth how the practicing happens, like in the case of more equal and inclusive social orders. Finally, diversity studies may adopt a conflict-sensitive strategy when interested in the tensions and contradictions among practices. This will allow scholars to gain insight into how a practice gains superiority over a competing one, relevant for when, for instance, a new diversity initiative is introduced.

Additionally, the critical dimension of a practice-based approach reminds diversity scholars that uncovering the spatial and temporal situated production and reproduction of a phenomenon should be done from a "political angle" (Ortner, 1984: 149). This latter requires asking critical questions to make the effects visible. Questions may inquire into the alignment (as in our example of career mentoring) or contradictions of the practice under study with other practices as well as into the effects this hanging together of practices have on those who reside within the nexus of practices (Nicolini, 2017; Nicolini \& Monteiro, 2017). As Gherardi and Rodeschini (2016: 279) remarks: "It is when the researchers interrogate the consequences of practices being practiced $[\ldots]$ that a critical gaze $[\ldots]$ opens up".

To suggest further conceptual routes into renewing the research agenda of diversity studies, we briefly re-conceptualize the diversity-related phenomena of diversity climate and whiteness along this line. Diversity climate is focused on employees' perceptions about the extent to which the organization successfully promotes fairness and the elimination of discrimination as well as the expression of, listening to, active valuing of, and integration of diverse perspectives. It is currently seen as having multiple predictors - inclusive HR practices, demographic composition of one's group, broader communities in which it is embedded, formally established diversity programs (Dwertmann et al., 2016). While we do not doubt the relevance of the content of the definition and the predictors, a practice-based theory of diversity would emphasize the performative nature of these 'predictors', aiming to 
uncover how, in a particular situation and time, inclusive HR practices, community practices and diversity practices hang together and produce a particular diversity climate. The latter is then no longer a personal perception but the net-effect of climate-producing practices, which can be inquired through critical questions related to empowerment, scope for agency and voice, as suggested by Nicolini (2017). Or, other questions that may be relevant can refer to the valorization of competences and the legitimatization of identities. Such practice-theory based diversity research on diversity climate then would enrich our understanding of the dynamics through which a diversity climate is created.

Similar, the notion of whiteness, an understudied yet critical notion in diversity studies, will be differently understood and studied. While its definition - 'the production and reproduction of dominance rather than subordination, normativity rather than marginality, and privilege rather than disadvantage' (Frankenberg, 1993, cited in Nkomo \& Al Ariss, 2014: 390) - already indicates a performative nature, a practice-theory based diversity study would further aim to uncover how the dominance of whiteness becomes unacknowledged. Possibly using a genealogical research strategy (Nicolini, 2017), longitudinal studies would be able to trace how over time certain practices produce in situ the emergence and stabilization of certain norms and privileges. They would use questions like: How did a norm originate and became embodied? How did we get where we are? And, through which sociomaterial arrangements did the practice travel in space and time? (Nicolini, 2013; 2017). Such research would complement current research focusing on black and white agency, white ignorance and white listening (Ahmed, 2007b; Swan, 2017), shedding new light on how whiteness and dominance emerges and becomes legitimized as it transpires and materializes amidst and through practices.

Finally and crucially, a practice-based theory of diversity may contribute to a better understanding of the continuing and persistent asymmetries that characterize diverse 
organizations. Starting from the assumption that behind all the apparently durable features of organizations (like horizontal and vertical segregation) there is some type of productive and reproductive work (Martin, 2003; Nicolini, 2013), it questions the 'natural' order of things. Practices that produce order will not be taken for granted; on the contrary, practice-based diversity studies carefully examine those practices and their associations that produce and reproduce the very resilient discriminatory, unequal social order of an organization. A practice-based theory of diversity thus promises a better understanding of how a 'natural' order of things is locked into a configuration of practices. We acknowledge though that this is a difficult promise. Also practice theorists themselves struggle with the challenge (see Table 1) of how practice theory can better contribute to our understanding of power and social phenomena which reflect enduring asymmetries (Watson, 2017). In this regard, Watson's proposal to especially focus on how practices are related to each other across different sites is extremely relevant to diversity, as is his plea that questions about connections between practices must take on "a sharper edge when the problem is that of explaining how some actors and sites come to be loci of a disproportionate capacity of shaping action elsewhere (Watson, 2017: 181). Much then seems to be gained if practice scholars and diversity scholars would join forces in understanding and conceptualizing the connections and nature of relationships between practices that produce stabilized patterns of power and reproduce inequalities within and across organizations (Nicolini, 2013; Watson, 2017). In this sense, the application of a practice approach within diversity studies may also benefit the further development of practice theory.

\section{CONCLUSION}

Our proposal to rejuvenate diversity research is to turn to practice theory and its rich theoretical approaches. From its relational ontology, we understand the mutually constitutive 
nature of social life, which directs diversity scholars to attend to recursive relations, not dualisms. From its conceptual ideas, we take away that the particular social order of a diverse organization is constantly accomplished through the enactment of practices. From its empirical project, we understand that diversity-related phenomena are to be explained through re-specifying them in terms of practices and their connections in space and time.

Taking on this form of theorizing is, as Feldman and Orlikowski (2011: 1250) remind us, in itself a practice which produces "particular kinds of consequences in the world, for which we as theoretical producers are responsible.” In the world today where diverse organizations continue to be characterized by discrimination and segregation, further fueled by extreme resistance and highly emotional reactions to migrants, refugees and globalization, diversity scholarship faces an immense responsibility. Theories that reduce social life to only a few elements are unlikely to explain the persistent inequality, complexity and sensitivity of diversity within and across organizations. A practice-based theory of diversity, with its emphasis on critically uncovering the taken-for-granted practices that produce problematic social orders but also its affirmative potential to identify situated practices that value diversity, can hopefully make this contribution. 


\section{REFERENCES}

Ahmed, S. 2007. The language of diversity. Ethnic and Racial Studies, 30: 235-256.

Ahmed, S. 2007b. A phenomenology of whiteness. Feminist Theory, 8: 149-168.

Alvesson, M., \& Sandberg, J. 2011. Generating research questions through problematization. Academy of Management Review, 36: 247-271.

Barad, K. 2003. Posthumanist performativity: Toward an understanding of how matter comes to matter. Signs: Journal of Women in Culture and Society, 28: 801-831.

Bell, E. L. 1990. The bicultural life experience of career-oriented black women. Journal of Organizational Behavior, 11: 459-477.

Bell, S. T., Villado, A. J., Lukasik, M. A., Belau, L., \& Briggs, A. L. 2011. Getting specific about demographic diversity variable and team performance relationships: A metaanalysis. Journal of Management, 37: 709-743.

Blake-Beard, S. 1999. The costs of living as an outsider within: An analysis of the mentoring relationships and career success of black and white women in the corporate sector. Journal of Career Development, 26: 21-36.

Blake-Beard, S., Kram, K. E., \& Murrell, A. J. 2017. Mentoring and diversity: Challenges and promises. New York: Routledge.

Bourdieu, P. 1977. Outline of a theory of practice. Cambridge: Cambridge University Press. Bourdieu, P. 1990. The logic of practice. Cambridge: Polity.

Bruni, A., Gherardi, S., \& Poggio, B. 2004. Doing gender, doing entrepreneurship: An ethnographic account of intertwined practices. Gender, Work and Organization, 11: 406429.

Butler, J. 1993. Bodies that matter: On the limits of "sex". London: Routledge.

Chia, R., \& Holt, R. 2008. On managerial knowledge. Management Learning, 39: 141-158.

Czarniawska, B. 2004. On time, space and action nets. Organization, 11: 773-791. 
Czarniaswka, B. 2007. Shadowing: And other techniques for doing fieldwork in modern societies. Copenhagen: Liber and Copenhagen Business School Press.

Dawson, B. L., Thomas, K. M., \& Goren, M. J. 2013. Career mentoring. In Q. M. Roberson (Ed.). The Oxford handbook of diversity and work: 300-314. Oxford: Oxford University Press.

Dick, P., \& Cassell, C. 2002. Barriers to managing diversity in a UK police constabulary: The role of discourse. Journal of Management Studies, 39: 953-976.

du Gay, P. 1996. Consumption and identity at work. London: Sage.

Dwertmann, D. J. G., Nishii L. H., \& van Knippenberg, D. 2016. Disentangling the fairness \& discrimination and synergy perspectives on diversity climate: Moving the field forward. Journal of Management, 42: 1136-1168.

Eikhof, R. D. 2017. Analysing decisions on diversity and opportunity in the cultural and creative industries: A new framework. Organization, 24: 289-307.

Emirbayer, M. 1997. Manifesto for a relational sociology. American Journal of Sociology, 103: $281-317$.

Essers, C., \& Benschop, Y. 2007. Enterprising identities: Female entrepreneurs of Turkish and Moroccan origin in The Netherlands. Organization Studies, 28: 49-69.

Fairclough, N. 1995. Critical discourse analysis: The critical study of language. London: Longman.

Farjoun, M. 2010. Beyond dualism: Stability and change as a duality. Academy of Management Review, 35: 202-225.

Faulkner, W. 2001. Doing gender in engineering workplace cultures. Engineering Studies, 1: 3-18.

Feldman, M. S., \& Orlikowski, W. J. 2011. Theorizing practice and practicing theory. Organization Science, 22: 1240-1253. 
Felski, R. 2011. Context stinks! New Literary History, 42: 573-591.

Finkel, R., Jones, D., Sang, K., \& Stoyanova R. D. 2017. Diversifying the creative: Creative work, creative industries, creative identities. Organization, 24: 281-288.

Foucault, M. 1976. The archaeology of knowledge. New York: Harper \& Row.

Fox, S. 1997. Situated learning theory versus traditional cognitive learning theory: Why management education should not ignore management learning. Systems Practice, 10: 727-747.

Frankenberg, R. 1993. White women, race matters: The social construction of whiteness. Minneapolis, MN: University of Minnesota Press.

Garfinkel, H. 1967. Studies in ethnomethodology. Englewood Cliffs: Prentice-Hall.

Gherardi, S. 2000. Practice-based theorizing on learning and knowing in organizations. Organization, 7: 211-223.

Gherardi, S. 2006. Organizational knowledge: The texture of workplace learning. Oxford: Blackwell Publishing.

Gherardi, S. 2012. How to conduct a practice-based study: Problems and methods. Cheltenham: Edward Elgar Publishing.

Gherardi, S. 2015. How the turn to practice may contribute to working life studies. Nordic Journal of Working Life Studies, 5(3): 13-25.

Gherardi, S. 2016. To start practice theorizing anew: The contribution of agencement and formativeness. Organization, 23: 680-698.

Gherardi, S. 2017. Sociomateriality in posthuman practice theory. In A. Hui, T. Schatzki, \& E. Shove (Eds.). The nexus of practices. Connections, constellations, practitioners: 3851. New York: Routledge.

Gherardi, S. 2018. Practices and knowledges. Teoria e Prática em Administração, 8(2): 3359. 
Gherardi, S., \& Rodeschini, G. 2016. Caring as a collective knowledgeable doing: About concern and being concerned. Management Learning, 47: 266-284.

Giddens, A. 1976. New rules of sociological method: A positive critique of interpretative sociologies. London: Hutchinson.

Giscombe, K. 2017. Creating effective mentoring programs for women of color. In A. Murrell, \& S. Blake Beard (Eds.). Mentoring diverse leaders: Creating change for people, processes and paradigms: 145-158. London: Routledge.

Grenfell, M. (Ed.) 2012. Pierre Bourdieu: Key concepts. New York: Routledge.

Haraway, D. 1991. Situated knowledges: The science question in feminism and the privilege of partial perspectives. In D. Haraway (Ed.). Simians, cyborgs and women: The reinvention of nature: 183-202. New York: Routledge.

Hardy, C., \& Phillips, N. 2004. Discourse and power. In S.R. Clegg, C. Hardy, \& W.R. Nord (Eds.). Handbook of organization studies: 229-316. London: Sage Publications.

Hardy, C., \& Thomas, R. 2015. Discourse in a material world. Journal of Management Studies, 52: 680-696.

Harrison, D. A., \& Klein, K. J. 2007. What's the difference? Diversity constructs as separation, variety, or disparity in organizations. Academy of Management Review, 32: 1199-1228.

Harrison, D. A., Price, K. H., \& Bell, M. P. 1998. Beyond relational demography: Time and the effects of surface-and deep-level diversity on work group cohesion. Academy of Management Journal, 41: 96-107.

Hollensbe, E., Wookey, C., Hickey, L., George, G., \& Nichols, C. V. 2014. Organizations with purpose. Academy of Management Journal, 57: 1227-1234.

Janssens, M., \& Zanoni, P. 2014. Alternative diversity management: Organizational practices fostering ethnic equality at work. Scandinavian Journal of Management, 30: 317-331. 
Jarzabkowski, P. 2003. Strategic practices: An activity perspective on continuity and change. Journal of Management Studies, 40: 23-55.

Johns, G. 2006. The essential impact of context on organizational behavior. Academy of Management Review, 31: 386-408.

Joshi, A., Liao, H., \& Roh, H. 2011. Bridging domains in workplace demography research: A review and reconceptualization. Journal of Management, 37: 521-552.

Joshi, A., \& Roh, H. 2009. The role of context in work team diversity research: A metaanalytical review. Academy of Management Journal, 52: 599-627.

Kalev, A., Dobbin, F., \& Kelly, E. 2006. Best practices or best guesses? Assessing the efficacy of corporate affirmative action and diversity policies. American Sociological Review, 71: 589-617.

Kelan, E. K. 2007. 'I don't know why': Accounting for the scarcity of women in ICT work. Women's Studies International Forum, 30: 499-511.

Konrad, A. M., \& Linnehan, F. 1995. Formalized HRM structures: Coordinating equal employment opportunity or concealing organizational practices? Academy of Management Journal, 38: 787-820.

Kram, K. E. 1985. Mentoring at work: Developmental relationships in organizational life. Glenview, IL: Scott, Foresman.

Latour, B. 2005. Reassembling the social: An introduction to actor-network-theory. Oxford: Oxford University Press.

Leslie, L. M., Mayer, D. M., \& Kravitz, D. A. 2014. The stigma of affirmative action: A stereotyping-based theory and meta-analytic test of the consequences for performance. Academy of Management Journal, 57: 964-989.

Lorbiecki, A., \& Jack, G. 2000. Critical turns in the evolution of diversity management. British Journal of Management, 11: 17-31. 
Maguire, S., \& Hardy, C. 2009. Discourse and deinstitutionalization: The decline of DDT. Academy of Management Journal, 52: 148-178.

Martin, P. Y. 2003. 'Said and done' versus 'saying and doing'. Gender and Society, 17: 342366.

Miettinen, R., Samra-Fredericks, D., \& Yanow, D. 2009. Re-turn to practice. An introductory essay. Organization Studies, 30: 1309-1327.

Nicolini, D. 2009a. Zooming in and out: Studying practices by switching theoretical lenses and trailing connections. Organization Studies, 30: 1391-1418.

Nicolini, D. 2009b. Articulating practice through the interview to the double. Management Learning, 40(2): 195-212.

Nicolini, D. 2011. Practice as the site of knowing: Insights from the field of telemedicine. Organization Science, 22: 602-620.

Nicolini, D. 2013. Practice theory, work, \& organization. Oxford: Oxford University Press.

Nicolini, D. 2017. Practice theory as a package of theory, method and vocabulary: Affordances and limitations. In M. Jones, B. Littig, \& A. Wroblenski (Eds.) Methodological reflections on practice oriented theories: 19-34. Berlin: Springer.

Nicolini, D., \& Monteiro, P. 2017. The practice approach: For a praxeology of organizational and management studies. In A. Langley, \& H. Tsoukas (Eds.). The Sage handbook of process organization studies: 110-126. London: Sage.

Nkomo, S., \& Al Ariss, A. 2014. The historical origins of ethnic (white) privilege in US organizations. Journal of Managerial Psychology, 29: 389-404.

Nkomo, S. M., Bell, M. P., Joshi, A., Roberts, L. M., \& Thatcher, S. 2016. Diversity at a critical juncture: New theories for a complex phenomenon. Call for Papers, Academy of Management Review Special Topic Forum.

O’Leary, J., \& Sandberg, J. 2017. Managers' practice of managing diversity revealed: A 
practice-theoretical account. Journal of Organizational Behavior, 38: 512-536.

Orlikowski, W. J. 2000. Using technology and constituting structures: A practice lens for studying technology in organizations. Organization Science, 11: 404-428.

Orlikowski, W. J., \& Scott, S. V. 2015. Exploring material-discursive practices. Journal of Management Studies, 52: 697-705.

Ortner, S. 1984. Theory in anthropology since the 60s'. Comparative Studies in Society and History, 26: 126-166.

Ostendorp, A., \& Steyaert, C. 2009. How different can differences be(come)?: Interpretative repertoires of diversity concepts in Swiss-based organizations. Scandinavian Journal of Management, 25: 374-384.

Poggio, B. 2006. Editorial: Outline of a theory of gender practices. Gender, Work $\boldsymbol{\&}$ Organization, 13: 225-233.

Prasad, P., \& Mills, A. 1997. From showcase to shadow: Understanding the dilemmas of managing workplace diversity. In P. Prasad, A. Mills, M. Elmes, \& A. Prasad (Eds). Managing the organizational melting pot: 3-27. Thousand Oaks: Sage.

Prasad, P., Pringle, J. K., \& Konrad, A. M. 2006. Examining the contours of workplace diversity: Concepts, contexts and challenges. In A. M. Konrad, P. Prasad, \& J. K. Pringle (Eds.). Handbook of workplace diversity: 1-22. London: Sage.

Putnam, L. L. 2015. Unpacking the dialectic: Alternative views on the discourse-materiality relationship. Journal of Management Studies, 52: 706-716.

Ragins, B. R. 1997. Diversified mentoring relationships in organizations: A power perspective. Academy of Management Review, 22: 482-521.

Ragins, B. R., \& Cotton, J. L. 1999. Mentor functions and outcomes: A comparison of men and women in formal and informal mentoring relationships. Journal of Applied Psychology, 84: 529-550. 
Ragins, B. R., Cotton, J. L., \& Miller, J. S. 2000. Marginal mentoring: The effects of type of mentor, quality of relationship, and program design on work and career attitudes. Academy of Management Journal, 43: 1177-1194.

Reckwitz, A. 2002. Towards a theory of social practices: A development in culturalist theorizing. European Journal of Social Theory, 5: 243-263.

Riach, K., Rumens, N., \& Tyler, M. 2014. Un/doing chrononormativity: Negotiating ageing, gender and sexuality in organizational life. Organization, 35: 1677-1698.

Roberson, Q. M. 2013. Conclusion: Future directions for diversity theory and research. In Q. M. Roberson (Ed.). The Oxford handbook of diversity and work: 461-469. Oxford: Oxford University Press.

Rodriguez, J. K., Holvino, E., Fletcher, J. K. \&, Nkomo, S. M. 2016. The theory and praxis of intersectionality in work and organisations: Where do we go from here? Gender, Work $\mathbb{\&}$ Organization, 23: 201-222.

Rynes, S. L., Bartunek, J. M., Dutton, J. E., \& Margolis, J. D. 2012. Care and compassion through an organizational lens: Opening up new possibilities. Academy of Management Review, 37: 503-523.

Sandberg, J., \& Dall'Alba, G. 2009. Returning to practice anew: A life-world perspective. Organization Studies, 30(12): 1349-1368.

Sandberg, J., \& Tsoukas, H. 2011. Grasping the logic of practice: Theorizing through practical rationality. Academy of Management Review, 36: 238-360.

Sandberg J., \& Tsoukas, H. 2016. Practice theory: What it is, its philosophical base, and what it offers organization studies. In R. A. Mir, H. Willmott, \& M. Greenwood (Eds.). Companion to philosophy in organization studies: 184-198. New York: Routledge.

Schatzki, T. R. 1996. Social practices: A Wittgensteinian approach to human activity and the social. Cambridge: Cambridge University Press. 
Schatzki, T. R. 2001. Introduction: Practice theory. In T. R. Schatzki, K. K. Cetina, \& E. von Savigny (Eds.). The practice turn in contemporary theory: 1-14. London: Routledge.

Schatzki, T. R. 2002. The site of the social: A philosophical account of the constitution of social life and change. University Park, PA: Penn State University Press.

Schatzki, T. R. 2005. The sites of organizations. Organization Studies, 26: 465-484.

Schatzki, T. R. 2016. Practice theory as flat ontology. In G. Spaargaren, D. Weenink, \& M. Lamers (Eds.) Practice theory and research: Exploring the dynamics of social life: 1842. Abingdon: Routledge.

Scollon, R 2001. Mediated discourse. The nexus of practice. New York: Routledge.

Shore, L. M., Randel, A. E., Chung, B. G., Dean, M. A., Ehrhart, K. H., \& Singh, G. 2011. Inclusion and diversity in work groups: A review and model for future research. Journal of Management, 37: 1262-1289.

Suchman, L., Blomberg, J., Orr, J. E., \& Trigg, R. 1999. Reconstructing technologies as social practice. American Behavioral Scientist, 43: 392-408.

Sullivan, S. E., \& Arthur, M. B. 2006. The evolution of the boundaryless career concept: Examining physical and psychological mobility. Journal of Vocational behavior, 69: 1929.

Steyaert, C. 2016. 'After' context. In F. Welter \& W.B. Gartner (Eds.). A Research Agenda for Entrepreneurship and Context: 28-40. Cheltenham: Edward Elgar Publishing.

Swan, E. 2017. What are white people to do? Listening, challenging ignorance, generous encounters and the 'not yet' as diversity research praxis. Gender, Work \& Organization, 24: $547-563$.

Tatli, A. 2011. A multi-layered exploration of the diversity management field: Diversity discourses, practices and practitioners in the UK. British Journal of Management, 22: 238-253. 
Tatli, A., \& Özbilgin, M. F. 2012. An emic approach to intersectional study of diversity at work: A Bourdieuan framing. International Journal of Management Reviews, 14: 180200.

Thomas, D. A. 1989. Mentoring and irrationality: The role of racial taboos. Human Resource Management, 28: 279-290.

Thomas, D. A. 1993. Racial dynamics in cross-race developmental relationships. Administrative Science Quarterly, 38: 169-194.

Thomas, D. A. 2001. The truth about mentoring minorities. Race matters. Harvard Business Review, 79(4): 98-107.

Townley, B. 2014. Bourdieu and organizational theory: A ghostly apparition?. In P.S. Adler, P. du Gay, G. Morgan \& M. Reed (Eds.). The Oxford handbook of sociology, social theory, and organization studies: 39-63. Oxford: Oxford University Press.

Tyler, M. 2018. Reassembling difference? Rethinking inclusion through/as embodied ethics. Human Relations, 1-21. 0018726718764264.

Tyler, M., \& Cohen, L. 2010. Spaces that matter: Gender performativity and organizational space. Organization Studies, 31: 175-198.

Vaara, E., \& Whittington, R. 2012. Strategy-as-practice: Taking social practices seriously. The Academy of Management Annals, 6(1): 285-336.

Van Laer K., \& Janssens M. 2017. Agency of ethnic minority employees: Struggles around identity, career and social change. Organization, 24: 198-217.

Wasserman, V., \& Frenkel, M. 2015. Spatial work in between glass ceilings and glass walls: Gender-class intersectionality and organizational aesthetics. Organization Studies, 36: 1485-1505.

Watson, M. 2017. Placing power in practice theory. In A. Hui, T. Schatzki, \& E. Shove (Eds.). The nexus of practices. Connections, constellations, practitioners: 169-182. New 
York: Routledge.

West, C., \& Zimmerman, D. 1987. Doing gender. Gender \& Society, 1: 125-151.

Yang, Y., \& Konrad, A. M. 2011. Understanding diversity management practices: Implications of institutional theory and resource-based theory. Group \& Organization Management, 36: 6-38.

Zanoni, P., \& Janssens, M. 2004. Deconstructing difference: The rhetoric of human resource managers' diversity discourses. Organization Studies, 25: 55-74.

Zanoni, P., Janssens, M., Benschop, Y., \& Nkomo, S. 2010. Unpacking diversity, grasping inequality: Rethinking difference through critical perspectives. Organization, 17: 9-29. 
TABLE 1

Ontological Assumptions of Dominant Diversity Theoretical Approaches and Practice Theory

\begin{tabular}{|c|c|c|c|}
\hline & $\begin{array}{c}\text { OB-Theory Based Diversity } \\
\text { Research }\end{array}$ & $\begin{array}{c}\text { Discourse-Theory Based } \\
\text { Diversity Research }\end{array}$ & Practice-Theory Based Research \\
\hline Social ontology & Individualism & Societism & Relational ontology \\
\hline Unit of analysis & $\begin{array}{l}\text { Individual and interpersonal } \\
\text { behavior }\end{array}$ & Discourses & Practices and their associations \\
\hline Components of unit of analysis & Cognitions, traits, competences & $\begin{array}{l}\text { Grand Discourses and small } \\
\text { discourses }\end{array}$ & $\begin{array}{l}\text { Bodily, material and discursive } \\
\text { resources }\end{array}$ \\
\hline Theoretical aim & $\begin{array}{l}\text { Formulate abstract propositions } \\
\text { and processes }\end{array}$ & $\begin{array}{l}\text { Conduct a critical analysis of } \\
\text { hegemony }\end{array}$ & $\begin{array}{l}\text { Re-articulate a social } \\
\text { phenomenon in terms of practices } \\
\text { and their associations }\end{array}$ \\
\hline Methodological choice & $\begin{array}{l}\text { Data collection through surveys, } \\
\text { experiments, interviews }\end{array}$ & $\begin{array}{l}\text { Data analysis of public texts and } \\
\text { interview transcripts }\end{array}$ & $\begin{array}{l}\text { Observation of the here-and-now } \\
\text { in a range of scenes of action }\end{array}$ \\
\hline Ways of overcoming dualisms & $\begin{array}{l}\text { Incorporate context in the } \\
\text { research design }\end{array}$ & $\begin{array}{l}\text { Attend to agentic capability of } \\
\text { engaging with discourses }\end{array}$ & $\begin{array}{l}\text { Attend to the process of mutual } \\
\text { constitution }\end{array}$ \\
\hline
\end{tabular}


Theoretical challenges

Context is a container of

variables - New micro/macro

divide
Little attention to the

sociomateriality of human action

- Agency/discourse divide

remains
Relational vocabulary - Practice

architecturism -Persistent

asymmetries 
TABLE 2

A Practice-Based Theory of Diversity

\begin{tabular}{ll}
\hline \multicolumn{1}{c}{ Principles } & \multicolumn{1}{c}{ Key Description } \\
\hline Post-dualistic ontological articulation & Diversity as a social phenomenon is relationally constituted \\
Unit of analysis is practice & Social life in a diverse organization is produced through practices - not only \\
& diversity management practices but also other management practices \\
Entanglement of body, materiality and discourse & A diversity practice is accomplished through the connection between bodies, \\
& tools and artefacts, and discursive resources \\
Practices are connected in time and space & A diversity practice is situated in time and space as actions and practices are \\
Explanations are grounded in what is empirically observable & The social order of a diverse organization is explained through observing and \\
& witnessing the practices in action
\end{tabular}


Maddy Janssens (Ph.D., KU Leuven) is a full professor of Work and Organization Studies at Faculty of Business and Economics, KU Leuven. Her current research centers on diversity in creative industries from a practice theory perspective, and ethics and politics in global organizations from a cosmopolitan perspective. (maddy.janssens@,kuleuven.be)

Chris Steyaert (Ph.D., KU Leuven) is a full professor of Organizational Psychology at the School of Management, University of Sankt Gallen. He has published in international journals and books in the area of organizational theory and entrepreneurship. His current interests concern creativity, multiplicity (diversity) and reflexivity drawing upon processual, practicebased and queer-theoretical approaches. (chris.steyaert@unisg.ch) 